\title{
Pengaruh Kecerdasan Emosional, Kecerdasan Intelektual, Love of Money Pada Persepsi Mahasiswa Mengenai Etika Profesi Akuntan
}

\author{
Komang Intan Kurniasari ${ }^{1}$ \\ I Gusti Ayu Nyoman Budiasih ${ }^{2}$
}

${ }^{1}$ Fakultas Ekonomi dan Bisnis Universitas Udayana (Unud), Bali, Indonesia
email: intandkurniasari@ @mail.com/telp: +6282 236645409
${ }^{1}$ Fakultas Ekonomi dan Bisnis Universitas Udayana (Unud), Bali, Indonesia

\begin{abstract}
ABSTRAK
Penelitian ini bertujuan untuk mengetahui pengaruh kecerdasan emosional, kecerdasan intelektual, dan love of money pada persepsi mahasiswa mengenai etika profesi akuntan. Teori yang digunakan dalam penelitian ini adalah Teori Motivasi. Populasi dalam penelitian ini adalah seluruh mahasiswa non reguler angkatan 2015 di Fakultas Ekonomi dan Bisnis Universitas Udayana. Jumlah sampel yang digunakan dalam penelitian ini sebanyak 114 responden dengan teknik penentuan sampel metode purposive sampling. Pengumpulan data dilakukan dengan metode kuesioner.Teknik analisis data yang digunakan adalah analisis regresi linier berganda. Hasil penelitian menunjukkan bahwa kecerdasan emosional, kecerdasan intelektual berpengaruh positif dan love of money berpengaruh negatif pada persepsi mahasiswa mengenai etika profesi akuntan.
\end{abstract}

Kata Kunci: kecerdasan emosional, kecerdasan intelektual, love of money

\begin{abstract}
This study aims to determine the effect of emotional intelligence, intellectual intelligence, and love of money on the perception of students about professional ethics of accountants. The theory used in this study is the Motivation Theory. The population in this study is all non-regular students class of 2015 in Faculty of Economics and Business Udayana University. The number of samples used in this study were 114 respondents with the technique of determining the sample purposive sampling method. Data collection was done by questionnaire method. The data analysis technique used was multiple linear regression analysis. The results showed that emotional intelligence, intellectual intelligence and positive influence of love of money negatively affect the perception of students about professional ethics of accountants.

Keywords: emotional intelligence, intellectual intelligence, love of money
\end{abstract}

\section{PENDAHULUAN}

Fenomena skandal keuangan dalam beberapa tahun terakhir pun semakin terbuka.

Pada tahun 2008 ketika terjadi krisis keuangan global, yang lagi-lagi diawali di Amerika serikat, terungkap sebuah skandal keuangan yang dilakukan oleh Bernard "Bernie" Madoff, seorang mantan kepala bursa non-eksekutif NASDAQ 
Komang Intan Kurniasari dan I Gusti Ayu Nyoman Budiasih. Pengaruh...

dan pimpinan firma keuangan Bernard L. Madoff Investment Securities LLC. Madoff melakukan penipuannya dengan menggunakan skema Ponzi atau yang dikenal juga dengan skema piramida. Skandal yang dilakukan Madoff tersebut bahkan disebut sebagai penipuan dengan menggunakan skema Ponzi terbesar yang pernah diungkap sepanjang sejarah. Penyimpangan yang dilakukan Madoff untuk menutup jejaknya selama melakukan penyelewengan tersebut adalah dengan cara memanipulasi laporan keuangan investor agar tidak terlihat kegiatan yang mencurigakan di dalam laporan keuangan tersebut. Dengan kerugian mencapai \$65 miliar, tindakan tersebut tentunya merugikan banyak orang yang menjadi investor di firma keuangannya. Selain merugikan banyak orang secara umum, hal tersebut juga merugikan kalangan akuntan profesional karena nama baik profesi akuntansi kembali tercoreng akibat dianggap menjadi pihak yang membantu Madoff dalam melakukan skandal tersebut.

Berdasarkan kasus-kasus skandal besar yang melibatkan kantor konsultan keuangan tanpa disadari menimbulkan reaksi mahasiswa yang membentuk suatu persepsi dari mahasiswa terhadap etika profesi di bidang akuntansi. Persepsi merupakan sikap atau tanggapan yang diberikan dalam respon maupun menafsirkan sebuah peristiwa. Mahasiswa akuntansi menjadi semakin tidak etis seiring dengan tingkat penyelesaian pendidikan akuntansi mereka. Mahasiswa akuntansi dinilai tidak terlalu sensitif terhadap isu etis jika dibandingkan dengan mahasiswa lain. Mahasiswa akuntansi juga disebutkan menganggap akuntansi secara keseluruhan adalah kegiatan yang teknis dan amoral. 
Kendati demikian, seorang akuntan harus mengerti dan sadar bahwa dia dapat bersikap sesuai dengan kode etik akuntan yang menjelaskan prinsip-prinsip etis yang harus dimiliki seorang akuntan, karena di dalam organisasi sikap adalah suatu hal yang penting karena sikap mempengaruhi perilaku kerja (Ikhsan dan Ishak, 2005 dalam Adinda, 2015). Kesadaran untuk bersikap etis tersebut didasari dari kemampuan individu untuk menentukan apa yang benar dan apa yang salah, dan kesadaran tersebut merupakan bagian dari kecerdasan emosional. Goleman (2002) menyatakan bahwa Intelligence Quotient (IQ) berperan 20\% terhadap kesuksesan dalam hidup. Sisanya ditentukan oleh Emotional Quotient $(E Q)$.

Kehidupan dalam lingkungan bermasyarakat, baik individu dengan individu ataupun individu dengan kelompok pasti memiliki nilai-nilai yang dijunjung bersama yang sering disebut norma dan diterapkan melalui perilaku etika. Hal tersebut bertujuan meminimalisasi terjadinya konflik atau adanya pihak yang dirugikan dalam lingkungan tersebut. Etika merupakan sikap moral yang berhubungan dengan pengambilan keputusan perilaku benar atau salah. Kebutuhan etika akan dirasakan ketika unsur etis dalam pendapat seseorang berbeda dengan pendapat orang lain, sehingga manusia harus berpedoman pada etika untuk mengetahui apa yang seharusnya dilakukan. Faktor yang berpengaruh pada keputusan atau tindakan tidak etis dalam sebuah perusahaan menurut Hoesada (2002) adalah kebutuhan individu, tidak adanya pedoman dalam diri individu, perilaku serta kebiasaan yang dilakukan oleh individu, lingkungan tidak etis di sekitar individu, perilaku atasan yang mendorong seseorang untuk 
melakukan tindakan tidak etis atau mengambil keputusan tidak etis. Masyarakat juga harus diyakinkan bahwa seorang akuntan akan melakukan perkerjaannya secara profesional dan bersikap etis. Seorang akuntan dituntut untuk bersikap etis sesuai kode etik yang berlaku. Untuk itu, mahasiswa akuntansi perlu diberikan pendidikan tentang sikap etis seorang akuntan. Disamping itu, keterampilan matematis telah berperan dalam menganalisis permasalahan keuangan terutama akuntansi. Hal tersebut didukung oleh penelitian yang menunjukkan bahwa dua puluh persen dari kesuksesan seseorang dihitung berdasarkan intelegensi, yaitu kemampuan untuk belajar, memahami dan mempertimbangkan segala sesuatu dengan baik (yang lebih sering diketahui sebagai IQ). Delapan puluh persen lainnya berdasarkan kecerdasan emosi, yaitu kemampuan untuk memahami diri sendiri dan berinteraksi dengan orang (Goleman, 2002).

Lingkungan kerja menuntut seseorang dalam bertindak profesional dan bersikap etis dalam berperilaku. Tidak hanya kepintaran yang diperlukan dalam bersaing dalam dunia kerja saat ini, namun kecerdasan emosi juga penting dimiliki. Catarina (2010:24) seseorang yang mampu mengatur emosional dengan baik maka akan timbul minat untuk mengembangkan potensi yang ada dalam dirinya, sehingga sumber daya manusia akan meningkat sesuai dengan kualitas yang diinginkan. Seorang mahasiswa akuntansi akan diberikan pendidikan mengenai pelaporan laporan keuangan dan kelak nantinya akan menjadi seorang akuntan. Akuntansi merupakan suatu sistem untuk menghasilkan informasi keuangan yang digunakan oleh para pemakainya dalam proses pengambilan keputusan bisnis. 
Goleman (2005:24) mendefenisikan kecerdasan emosional sebagai berikut: “Kecerdasan emosional adalah kemampuan mengenali perasaan diri sendiri dan perasaan orang lain, memotivasi diri sendiri, serta mengelola emosi dengan baik pada diri sendiri dan dalam hubungan dengan orang lain”. Purba (1999) dalam Fabiola (2005) berpendapat bahwa kecerdasan emosi adalah kemampuan di bidang emosi yaitu kesanggupan menghadapi frustasi, kemampuan mengendalikan emosi, semangat optimisme, dan kemampuan menjalin hubungan dengan orang lain atau empati. Hal tersebut seperti yang dikemukakan Patton (1998) dalam Fabiola (2005) bahwa penggunaan emosi yang efektif akan dapat mencapai tujuan dalam membangun hubungan yang produktif dan meraih keberhasilan kerja. Kecerdasan dalam arti umum adalah suatu kemampuan umum yang membedakan kualitas orang yang satu dengan orang yang lain, kecerdasan intelektual lazim disebut dengan inteligensi. Inteligensi adalah kemampuan kognitif yang dimiliki organisme untuk menyesuaikan diri secara efektif pada lingkungan yang kompleks dan selalu berubah serta dipengaruhi oleh faktor genetik.

(Boyatzis, et al. 2000) menyatakan, bahwa kecerdasan emosional merupakan komponen yang membuat seseorang menjadi pintar menggunakan emosi. Penelitian yang dilakukan oleh Higgs (2002) yang mengatakan bahwa kecerdasan emosional merupakan syarat kunci kesuksesan dan keahlian seseorang. Kunci sukses lainnya antara lain adalah kesadaran diri, pengaturan diri, motivasi dan empati. Keempat-empatnya berperan dan terpercaya sebagai indikasi sukses di tempat kerja. Namun seiring berjalannya waktu, kecerdasan 
Komang Intan Kurniasari dan I Gusti Ayu Nyoman Budiasih. Pengaruh...

intelektual bukanlah satu-satunya hal yang dapat menentukan kesuksesan. Menurut Goleman (2006), 20 persen kesuksesan berasal dari kecerdasan intelektual sedangkan kekuatan-kekuatan lain termasuk kecerdasan emosional mempengaruhi kesuksesan sebesar 80 persen.

Tang, et al. (1992) memperkenalkan konsep pengukuran Money Ethic Scale (MES) dan konsep “love of money" sebagai literatur yang menjelaskan tentang ukuran afinitas subjektif seseorang terhadap uang. Love of money mengukur seberapa besar afinitas seseorang terhadap uang yang pada akhirnya akan mempengaruhi persepsi etisnya. Uang sering dipandang buruk dalam kehidupan, bahkan ada ungkapan yang mengatakan bahwa uang adalah akar dari segala kejahatan. Alasannya tentu tidak jauh dari berbagai aksi kejahatan yang selalu disangkut-pautkan dengan kebutuhan akan uang. Penelitian yang dilakukan Tang dan Chiu (2003) menyimpulkan bahwa karyawan asal Hong Kong yang dengan love of money yang tinggi tidak memiliki kepuasan kerja setinggi rekan-rekan kerjanya dengan love of money yang rendah, sehingga ada kemungkinan pekerja dengan love of money yang tinggi akan melakukan tindakan-tindakan yang tidak etis. Menurut Tang dan Chiu (2003) dalam Mulyani (2015) love of money adalah sebagai perilaku seseorang terhadap uang, pengertian seseorang terhadap uang, serta keinginan dan aspirasi terhadap uang.

Moekijat (1995) dalam Lestari (2016), memaparkan motivasi memiliki makna serupa, yakni suatu daya dalam melaksanakan suatu hal atau pekerjaan. Motivasi yang dimiliki seseorang merupakan kekuatan tanpa adanya kelemahan 
maupun faktor lainnya yang dimiliki oleh setiap individu. Berdasarkan teori motivasi tersebut, untuk mencapai apa yang menjadi tujuan diperlukan kecerdasan emosional pada individu. Kecerdasan emosional adalah kemampuan seseorang untuk menerima, menilai, mengelola, serta mengontrol emosi dirinya dan orang lain disekitarnya. Kecerdasan emosional ini dipengaruhi lingkungan, tidak menetap dan dapat berubah-ubah serta dikembangkan. Kecerdasan emosional berperan penting dalam pekerjaan seseorang (Agus Santika, 2016) . Kecerdasan emosional sebagai kemampuan memantau dan mengendalikan perasaan diri sendiri dan orang lain serta menggunakan perasaan itu untuk memandu pikiran dan tindakan. Kecerdasan emosi menuntut pemilikan perasaan, untuk belajar mengakui, menghargai perasaan pada diri dan orang lain serta menanggapinya dengan tepat, menerapkan secara efektif energi emosi dalam kehidupan sehari-hari (Catarina, 2010).

$\mathrm{H}_{1}$ : Semakin tinggi tingkat kecerdasan emosional maka makin tinggi persepsi mahasiswa mengenai etika profesi akuntan

Menurut William Stren dalam Purwanto, (2003:52), Kecerdasan intelektual adalah kesanggupan untuk menyesuaikan diri kepada kebutuhan baru, dengan menggunakan alat-alat berfikir yang sesuai dengan tujuan. Wechler dalam Pratiwi (2011) merumuskan kecerdasan intelektual sebagai keseluruhan kemampuan individu untuk berpikir dan bertindak secara terarah serta kemampuan mengelola dan meguasai lingkungan secara efektif. Menurut Yani (2011) Kecerdasan intelektual merupakan kecerdasan yang sangat dibutuhkan dalam keberhasilan seseorang, kecerdasan intelektual tetap mempengaruhi pola fikir seorang 
mahasiswa. karena kecerdasan intelektual merupakan kecerdasan pertama yang dikembangkan yang mampu membuat seorang mahasiswa berfikir secara rasional untuk belajar akuntansi dan memahaminya. Oleh karena itu, seorang mahasiswa akuntansi yang memiliki kecerdasan intelektual yang baik maka mampu memahami akuntansi dan dapat membaca dengan penuh pemahaman serta menunjukkan keingintahuan terhadap akuntansi. Berdasarkan uraian tersebut, maka dapat dibuat hipotesis sebagai berikut:

$\mathrm{H}_{2}$ : Semakin tinggi tingkat kecerdasan intelektual maka makin tinggi persepsi mahasiswa mengenai etika profesi akuntan

Love of money sangat berkaitan dengan sifat tamak dan rakus. Seseorang dengan love of money yang tinggi cenderung memiliki kecintaan berlebihan pada uang dan akan menilai segala sesuatu hal dengan uang (Ari, 2018). Sesuai dengan maslow's need hierarchy teory menurut Hasibuaan (2003:103) manusia memiliki sejumlah kebutuhan yang diklarifikasikan menjadi beberapa tingkatan kebutuhan, yakni: fisiologis, kebutuhan akan rasa aman, harga diri, dan kebutuhan aktualisasi. Kebutuhan tersebut dapat terpenuhi salah satunya dengan uang maka uang mempunyai peranan yang sangat penting dalam motivasi namun kecintaan yang berlebihan terhadap uang juga akan menimbulkan ketamakan. Ketamakan dinilai merupakan perilaku tidak etis, sehingga sehingga seseorang yang mempunyai tingkat love of money tinggi maka ia akan cenderung berperilaku tidak etis. Menurut penelitian yang dilakukan oleh Charismawati (2011) yang meneliti tentang hubungan love of money terhadap persepsi etika mahasiswa menunjukkan bahwa terdapat hubungan negatif antara tingkat love of money 
pada persepsi etis mahasiswa akuntansi . Semakin besar tingkat love of money mahasiswa maka akan semakin rendah tingkat persepsi etis mereka. Menurut penelitian yang dilakukan Aziz (2015) yang meneliti pengaruh love of money dan machiavellian terhadap persepsi etis mahasiswa akuntansi menyatakan love of money dengan persepsi etika mahasiswa mempunyai pengaruh yang negatif.

$\mathrm{H}_{3}$ : Semakin tinggi tingkat love of money maka makin rendah persepsi mahasiswa mengenai etika profesi akuntan

\section{METODE PENELITIAN}

Penelitian ini menggunakan pendekatan kuantitatif yang berbentuk asosiatif. Pendekatan kuantitatif merupakan metode penelitian menggunakan data berupa angka serta dianalisis menggunakan statistic (Sugiyono, 2014:12). Penelitian berbentuk asosiatif merupakan penelitian yang bertujuan untuk mengetahui hubungan antara dua variable atau lebih (Sugiyono, 2014:55). Dalam penelitian ini membahas dan menguji pengaruh kecerdasan emosional, kecerdasan intelektual, dan love of money terhadap etika profesi akuntan. Penelitian ini dilakukan di Fakultas Ekonomi dan Bisnis jurusan akuntansi angkatan 2015 Program S1 non reguler dengan menyebarkan kuisioner yang beralamat di jln. P.B. Sudirman Denpasar.

Kecerdasan emosional merupakan kemampuan merasakan, memahami dan secara efektif menerapkan daya dan kepekaan emosi sebagai sumber energi, informasi, koneksi dan pengaruh yang manusiawi. Dengan kemampuan ini maka mahasiswa akan mampu untuk mengenal siapa dirinya, mengendalikan dirinya, memotivasi dirinya, berempati terhadap lingkungan sekitarnya dan memiliki 
keterampilan sosial yang akan meningkatan kualitas pemahaman mereka tentang akuntansi karena adanya proses belajar yang didasari oleh kesadaran mahasiswa itu sendiri.

Variabel ini diukur dengan skala Likert empat poin, yaitu $1=$ sangat tidak setuju, 2 = tidak setuju, 3 = setuju, 4 = sangat setuju.Indikator-indikator dari kecerdasan emosional menurut (Dewi, 2012) sebagai berikut: Kesadaran diri, Pengendalian diri, Motivasi diri, Empati diri, dan Keterampilan sosial.

Menurut Robins dan Judge (2008: 57) dalam Dwijayanti (2009) mengatakan bahwa kecerdasan intelektual adalah kemampuan yang di butuhkan untuk melakukan berbagai aktivitas mental berpikir, menalar dan memecahkan masalah. Dalam variabel ini terdapat pertanyaan yaitu 10 pernyataan yang diadopsi dari penelitian Dwijayanti (2009) dengan indikator: Kemampuan memecahkan masalah, Intelegensi Verbal, dan Intelegensi Praktis. Variabel ini diukur dengan skala Likert empat poin, yaitu 1 = sangat tidak setuju, $2=$ tidak setuju, $3=$ setuju, 4 = sangat setuju (Adinda, 2015).

Tang (1992) meperkenalkan konsep The Love of money untuk literatur psikologis. Untuk mengukur love of money, digunakan Money Ethics Scale (MES) yang dikembangkan oleh (Tang et al. 1992). Skala ini mengukur sikap manusia terhadap uang. Tang dan rekan-rekannya kemudian mengembangkan versi beberapa skala yang lebih pendek, tetapi penelitian ini menggunakan skala asli karena kedalaman dan cakupan yang komprehensif dari sikap terhadap uang. Tiga puluh lima item kuesioner diterjemahkan ke banyak bahasa dan berhasil digunakan dalam banyak studi sejak publikasi aslinya. Kuesioner menghasilkan 
sepuluh faktor yang diidentifkasi sebagai berikut: Budget, Evil, Equty, Success, self expression, Social influence, Power of Control, Happiness, Richness, dan Motivator. Variabel ini diukur dengan skala Likert empat poin, yaitu $1=$ sangat tidak setuju, 2 = tidak setuju, 3 = setuju, 4 = sangat setuju (Kurniawan, 2017).

Persepsi etika adalah bagaimana seseorang bersikap menilai satu keadaan atau perilaku pelanggaran. Instrumen tersebut yaitu Ethical Rating (ERATING) yang terdiri dari 16 pernyataan dengan skala likert 1-4 yang mengukur persepsi etika, semakin etis dengan skor rendah dan persepsi etika tidak etis dengan skor tinggi. Responden mencatat persepsinya tentang etika tindakan tersebut pada skala empat poin mulai dari 1 (sangat tidak setuju) ini berarti tindakan tersebut sangat etis, sampai 4 (sangat setuju) yang berarti tindakan tersebut sangat tidak etis (Kurniawan, 2017).

Populasi dalam penelitian ini adalah mahasiswa jurusan akuntansi Fakultas Ekonomi dan Bisnis Universitas Udayana Non Reguler angkatan 2015 yang berjumlah 184 orang. Peneliti memilih mahasiswa akuntansi angkatan 2015 non reguler berjumlah 184 orang karena untuk mempermudah keakuratan dalam memperoleh data yang digunakan sebagai sampel.

Metode penentuan sempel dalam penelitian ini menggunakan metode non probability sampling dengan teknik secara purposive sampling, yaitu teknik pengambilan sampel dengan kriteria tertentu, dimana anggota sampel yang dipilih dapat mewakili sifat-sifat populasi. Adapun kriteria sampel yang digunakan adalah 1) Mahasiswa yang sedang berada pada semester 6; 2) Mahasiswa yang sudah menempu mata kuliah Etika Bisnis. 
Sebelum dilakukan teknik analisis terhadap data yang dikumpulkan terlebih dahulu dilakukan pengujian instrumen penelitian dalam hal ini adalah pengujian validitas dan reliabilitas. Uji asumsi klasik dilakukan untuk menguji hipotesis yang telah dibuat dalam suatu penelitian yang menunjukan bahwa model regresi tersebut layak atau tidak untuk dilakukan ke pengujian tahap selanjutnya. Uji asumsi klasik bertujuan untuk menguji kelayakan model yang dibuat sebelum melakukan model regresi.

Peneliti berusaha mengumpulkan data yang akurat dengan menggunakan kuesioner. Kuesioner merupakan teknik pengumpulan data yang dilakukan dengan cara memberi beberapa pernyataan atau pertanyaan tertulis kepada responden untuk dijawab (Sugiyono, 2017:292). Jenis data dalam penelitian ini yaitu data kuantitatif yang merupakan data yang berbentuk angka atau data kualitatif yang diangkakan. Data kuantitatif dalam penelitian adalah jumlah responden yang menjawab kuesioner. Pada penelitian ini peneliti menggunakan data primer.

Data primer merupakan data yang di kumpulkan secara langsung dari objek yang di teliti. Data primer dalam penelitian ini meliputi jawaban responden melalui penyebaran kuesioner yang berupa beberapa butir pernyataan untuk variabel pengaruh kecerdasan emosional, kecerdasan intelektual dan love of money pada persepsi mahasiswa mengenai etika profesi akuntan. Penelitian ini menggunakan kuesioner yang diberikan secara langsung kepada responden yang berada di lokasi penelitian, dan diukur dengan skala likert 4 . Nilai dari skala likert yaitu, skor 1 = sangat tidak setuju (STS), 2 = tidak setuju (TS), 3 = setuju (S), dan 
4 = sangat setuju $(\mathrm{SS})$.

Sebelum dilakukan teknik analisis terhadap data yang dikumpulkan terlebih dahulu dilakukan pengujian instrumen penelitian dalam hal ini adalah pengujian validitas dan reliabilitas. Uji asumsi klasik dilakukan untuk menguji hipotesis yang telah dibuat dalam suatu penelitian yang menunjukan bahwa model regresi tersebut layak atau tidak untuk dilakukan ke pengujian tahap selanjutnya. Uji asumsi klasik bertujuan untuk menguji kelayakan model yang dibuat sebelum melakukan model regresi.

Analisis regresi linear berganda dilakukan untuk mengetahui hubungan antar lebih dari dua variabel, yaitu satu variabel sebagai variabel dependen dan beberapa variabel lain sebagai variabel independen. Pengujian hipotesis ini dilakukan dengan menggunakan alat statistik SPSS (statistical package for social science) dengan tingkat signifikasi 5\% $(\alpha=0,05)$. Pengujian hipotesis dengan analisis regresi linier berganda diformulasikan sebagai berikut.

$$
\mathrm{Y}=\mathrm{a}+\mathrm{b}_{1} \mathrm{X}_{1}+\mathrm{b}_{2} \mathrm{X}_{2}+\mathrm{b}_{3} \mathrm{X}_{3}+\varepsilon
$$

Keterangan:

$$
\begin{array}{ll}
\mathrm{Y} & =\text { Persepsi mahasiswa terhadap etika profesi akuntan } \\
\mathrm{a} & =\text { Nilai konstanta } \\
\mathrm{X}_{1} & =\text { Kecerdasan emosional } \\
\mathrm{X}_{2} & =\text { Kecerdasan Intelektual } \\
\mathrm{X}_{3} & =\text { Love of Money } \\
\mathrm{b}_{1}-\mathrm{b}_{2} & =\text { Koefisien regresi variabel independen } \\
\varepsilon & =\text { Standar error }
\end{array}
$$

Ketepatan dari fungsi regresi sampel dalam menaksir nilai aktual diukur dari goodness of fit-nya (Ghozali, 2016:97). Secara statistik hal tersebut dapat dilihat dari nilai koefisien determinasi $\left(\mathrm{R}^{2}\right)$, nilai statistik $\mathrm{F}$ (uji kelayakan model), dan 
nilai statistik t (Uji Signifikansi parameter individual).

Nilai koefisien determinasi menunjukan seberapa jauh kemampuan variabel independen dalam menerangkan variasi variabel dependen. Dalam perhitungan statistik ini, nilai $\mathrm{R}^{2}$ yang digunakan adalah adjusted $\mathrm{R}^{2}$ karena ini merupakan salah satu indikator untuk mengetahui pengaruh penambahan satu variabel independen ke dalam satu persamaan regresi. Nilai dari adjusted $\mathrm{R}^{2}$ benar-benar menunjukan pengaruh variabel independen pada variabel dependen. Koefisien determinasi atau kuadrat dari koefisien korelasi memiliki nilai 0 sampai dengan 1 atau $0 \leq \mathrm{R}^{2} \leq 1$. Koefisien determinasi sama dengan satu berarti variabel independen berpengaruh secara sempurna pada variabel dependen dan jika berpengaruh pada variabel dependen (Ghozali,2016).

Uji statistik F digunakan untuk menguji kelayakan atau validitas dari suatu model regresi berganda dan untuk mengetahui apakah model penelitian dapat digunakan untuk memprediksi variabel dependen. Kriteria penilaian dilakukan dengan membandingkan nilai signifikan $F_{\text {hitung }}$ dengan nilai signifikan $\alpha$. Apabila nilai signifikan $F_{\text {hitung }}$ kurang dari $\alpha=0,05$ maka model penelitian dapat atau layak digunakan. Alternatif lain dapat dilakukan dengan melihat hasil regresi dengan program SPSS, yaitu melihat nilai F yang disajikan. Apabila tingkat signifikan $\mathrm{F} \leq \alpha=0,05$, maka $\mathrm{H}_{1}$ diterima dan $\mathrm{H}_{0}$ ditolak. Namun, bila tingkat signifikan $\mathrm{F}>\alpha=0,05$, maka $\mathrm{H}_{1}$ ditolak dan $\mathrm{H}_{0}$ diterima.

Uji $\mathrm{t}$ digunakan untuk mengetahui pengaruh masing-masing variabel independen terhadap variabel dependen (Ghozali, 2016:178). Kriteria penilaian dilakukan dengan melihat hasil regresi dengan program SPSS, yaitu 
membandingkan tingkat signifikan masing-masing variabel bebas dengan $\alpha=$ 0,05. Apabila tingkat signifikansi $\mathrm{t} \leq \alpha=0,05$, maka $\mathrm{H}_{1}$ diterima dan $\mathrm{H}_{0}$ ditolak. Namun, bila tingkat signifikansi $\mathrm{t}>\alpha=0,05$, maha $\mathrm{H}_{1}$ ditolak dan $\mathrm{H}_{0}$ diterima.

\section{HASIL DAN PEMBAHASAN}

Responden yang digunakan dalam penelitian ini adalah seluruh mahasiswa jurusan Akuntansi Non Reguler angkatan 2015 di Fakultas Ekonomi dan Bisnis Universitas Udayana sebanyak 184 responden. Peneliti telah menyebarkan kuesioner sebanyak 184 eksemplar dengan rincian dapat dilihat pada Tabel 1 berikut:

Tabel 1. Rincian Pengiriman dan Pengembalian Kuesioner

\begin{tabular}{lcc}
\hline Keterangan & Jumlah & Persentase (\%) \\
\hline kuesioner yang disebar & 184 & 100 \\
Kuesioner yang tidak dikembalikan & 61 & 33,15 \\
Kuesioner yang dikembalikan & 123 & 66,85 \\
Kuesioner yang gugur (tidak lengkap) & 9 & 7,31 \\
Kuesioner yang digunakan & 114 & 92,68 \\
\hline
\end{tabular}

Sumber: Data diolah, 2018

Tabel 1 menunjukkan bahwa jumah kuesioner yang terpakai adalah 114 kuesioner dari 184 kuesioner yang disebarkan, ini diakibatkan karena ketidak mampuan peneliti dalam menyebarkan seluruh kuesioner, karena keterbatasan waktu dan beberapa responden yang diteliti sudah menyelesaikan masa kuliah mereka. Jadi responden yang digunakan dalam penelitian ini sebanyak 114 responden $(92,68 \%)$. 
Karakteristik responden yang diteliti dalam penelitian ini meliputi jenis kelamin dan usia. Ringkasan karakteristik responden dapat dilihat pada Tabel 2 sebagai berikut.

Tabel 2.

Karakteristik Responden

\begin{tabular}{cclcc}
\hline No. & Karakteristik & Klasifikasi & Jumlah (orang) & Presentase (\%) \\
\hline 1 & \multirow{2}{*}{ Jenis Kelamin } & Laki-laki & 56 & $49,55 \%$ \\
& & Perempuan & & \\
& \multirow{4}{*}{2} & & 58 & $50,88 \%$ \\
& & 114 & 100 \\
& \multirow{2}{*}{ Usia } & 20 Tahun & 22 & $19,29 \%$ \\
& 21 Tahun & 35 & $30.70 \%$ \\
& 22 Tahun & 54 & $47,37 \%$ \\
& 23 Tahun & 3 & $2.63 \%$ \\
& & & 114 & 100 \\
\hline
\end{tabular}

Sumber: Data diolah, 2018

Jenis kelamin responden digunakan sebagai acuan untuk ketegasan dan keterlibatan yang memengaruhi emosi dalam mengambil suatu keputusan. Berdasarkan Tabel 2, dapat dilihat bahwa responden dalam penelitian ini adalah responden laki-laki dengan jumlah 56 orang $(49,55 \%)$ dan responden perempuan berjumlah 58 orang $(50,88 \%)$.

Usia responden digunakan untuk menggambarkan tingkat kedewasaan seseorang dalam melakukan aktifitas yang mempengaruhi sikap dalam mengambil suatu keputusan. Berdasarkan tabel 2, dapat dilihat bahwa responden yang berusia 20 tahun sebanyak 22 orang $(19,29 \%)$, responden yang berusia 21 tahun sebanyak 35 orang $(30,70 \%)$, responden yang berusia 22 tahun sebanyak 54 orang $(47,37 \%)$ dan responden yang berusia 23 tahun sebanyak 3 orang $(2,63 \%)$.

Jumah kuesioner yang terpakai adalah 114 kuesioner dari 184 kuesioner yang disebarkan, ini diakibatkan karena ketidak mampuan peneliti dalam 
menyebarkan seluruh kuesioner, karena keterbatasan waktu dan beberapa responden yang diteliti sudah menyelesaikan masa kuliah mereka. Jadi responden yang digunakan dalam penelitian ini sebanyak 114 responden $(92,68 \%)$.

Statistik Deskriptif dalam penelitian ini disajikan untuk memberikan informasi tentang karakteristik variabel penelitian, antara lain nilai minimum, maksimum, rata-rata dan standar deviasi pada data berskala interval. Pengukuran rata-rata umumnya digunakan untuk mengukur nilai sentral dari suatu distribusi sedangkan untuk mengukur perbedaan ini data yang diteliti dengan nilai rataratanya digunakan standar deviasi. Statistik deskriptif dapat dilihar pada Tabel 3 berikut:

Tabel 3.

Hasil Statistik Deskriptif

\begin{tabular}{lccccc}
\hline \multicolumn{1}{c}{ Variabel } & N & Minimum & Maximum & Mean & $\begin{array}{c}\text { Deviasi } \\
\text { Standar }\end{array}$ \\
\hline Kec. Emosional & 114 & 39 & 52 & 43,78 & 1,852 \\
Kec. Intelektual & 114 & 25 & 60 & 30,08 & 3,072 \\
Love of money & 114 & 75 & 113 & 103,07 & 5,109 \\
Profesi Akuntan & 114 & 40 & 54 & 47,46 & 2,262 \\
\hline
\end{tabular}

Sumber: Data diolah, 2018

Banyaknya kuesioner yang diolah adalah 114 kuesioner untuk masingmasing variabel. Variabel kecerdasan emosional $\left(\mathrm{X}_{1}\right)$ mempunyai nilai minimum sebesar 39, nilai maksimum sebesar 52, dan nilai rata-rata sebesar 43,78. Hal ini berarti bahwa berdasarkan hasil statistik deskriptif tingkat kecerdasan emosional rata- rata tinggi. Deviasi standar sebesar 1,852 , hal ini berarti bahwa berdasarkan hasil statistik deskriptif terjadi perbedaan nilai kecerdasan emosional yang diteliti terhadap nilai rata-rata sebesar 1,852 . 
Variabel kecerdasan intelektual $\left(\mathrm{X}_{2}\right)$ mempunyai nilai minimum sebesar 25, nilai maksimum sebesar 60 , dan nilai rata-rata sebesar 30.08 . Hal ini berarti bahwa berdasarkan hasil statistik deskriptif nilai kecerdasan intelektual rata- rata tinggi. Deviasi standar sebesar 3,072, hal ini berarti bahwa berdasarkan hasil statistik deskriptif terjadi perbedaan nilai kecerdasan intelektual yang diteliti terhadap nilai rata-rata sebesar 3,072.

Variabel love of money $\left(\mathrm{X}_{3}\right)$ mempunyai nilai minimum sebesar 75 , nilai maksimum sebesar 113, dan nilai rata-rata sebesar 103,07. Hal ini berarti bahwa berdasarkan hasil statistik deskriptif nilai love of money rata- rata tinggi. Deviasi standar sebesar 5,109, hal ini berarti bahwa berdasarkan hasil statistik deskriptif terjadi perbedaan nilai love of money yang diteliti terhadap nilai rata-rata sebesar 5,109 .

Variabel Persepsi mahasiswa mengenai etika profesi akuntan (Y) mempunyai nilai minimum sebesar 40 , nilai maksimum sebesar 54, dan nilai ratarata sebesar 47,46. Hal ini berarti bahwa berdasarkan hasil statistik deskriptif nilai persepsi mahasiswa mengenai etika profesi akuntan rata- rata tinggi. Deviasi standar sebesar 2,262, hal ini berarti bahwa berdasarkan hasil statistik deskriptif terjadi perbedaan nilai minat berkarir menjadi akuntan publik yang diteliti terhadap nilai rata-rata sebesar 2,262.

Analisis regresi linier berganda merupakan analisis yang digunakan untuk mengetahui pengaruh kecerdasan emosional, Kecerdasan Intektual, Love of money pada presepsi mahasiswa mengenai profesi akuntan. Analisis tersebut diolah 
ISSN: 2302-8556

E-Jurnal Akuntansi Universitas Udayana

Vol.25.1.Oktober (2018): 773-798

menggunakan program komputer, yaitu Statistical Package for Social Science (SPSS). Hasil dari analisis tersebut dapat dilihat pada Tabel 4.

Tabel 4.

Hasil Uji Analisis Regresi Linier Berganda

\begin{tabular}{|c|c|c|c|c|c|}
\hline \multirow{2}{*}{ Model } & \multicolumn{2}{|c|}{ Unstandardized Coefficients } & \multirow{2}{*}{$\begin{array}{c}\text { Standardized } \\
\text { Coefficients } \\
\text { Beta }\end{array}$} & \multirow{2}{*}{$\mathbf{t}$} & \multirow{2}{*}{ Sig. } \\
\hline & B & Std. Error & & & \\
\hline (Constant) & 28,394 & 8,389 & & 3,385 & 0,001 \\
\hline Kec.Emosional & 0,199 & 0,115 & 0,081 & 2,857 & 0,003 \\
\hline Kec.Intelektual & 0,205 & 0,061 & 0,135 & 2,635 & 0,015 \\
\hline Love of Money & $-0,198$ & 0,041 & $-0,447$ & $-1,097$ & 0,008 \\
\hline $\mathrm{R}$ & 0,724 & & & & \\
\hline $\mathrm{R}^{2}$ & 0,525 & & & & \\
\hline Adjusted $\mathrm{R}^{2}$ & 0,517 & & & & \\
\hline F hitung & 13,402 & & & & \\
\hline Sig. F & 0,000 & & & & \\
\hline
\end{tabular}

Tabel 4 menunjukkan nilai koefisien regresi dari variabel bebas (kecerdasan emosional, kecerdasan intelektual, love of money) dan nilai konstanta variabel terikat (presepsi mahasiswa mengenai profesi akuntan), maka diperoleh persamaan regresi linier berganda sebagai berikut:

$$
\mathrm{Y}=3,385+0,199\left(\mathrm{X}_{1}\right)+0,205\left(\mathrm{X}_{2}\right)+-0,198\left(\mathrm{X}_{3}\right)+\varepsilon(2)
$$

Berdasarkan persamaan tersebut, maka pengaruh kecerdasan emosional, kecerdasan intelektual, dan love of money pada persepsi mahasiswa mengenai profesi akuntan dapat diartikan yaitu diketahui konstanta besarnya 3,385 mengandung arti jika kecerdasan emosional $\left(\mathrm{X}_{1}\right)$, kecerdasan intelektual $\left(\mathrm{X}_{2}\right)$, dan love of money $\left(\mathrm{X}_{3}\right)$ dianggap konstan pada angka 0 , maka nilai pada persepsi mahasiswa mengenai eti profesi akuntan (Y) sebesar 3,385. $\beta_{1}=0,119$; berarti apabila variabel kecerdasan emosional $\left(\mathrm{X}_{1}\right)$ meningkat, maka akan mengakibatkan peningkatan pada persepsi mahasiswa mengenai profesi akuntan (Y), dengan 
asumsi variabel bebas lainnya dianggap konstan. $\beta_{2}=0,205$; berarti apabila variabel kecerdasan intelektual $\left(\mathrm{X}_{2}\right)$ meningkat, maka akan mengakibatkan peningkatan pada persepsi mahasiswa mengenai profesi akuntan (Y), dengan asumsi variabel bebas lainnya dianggap konstan. $\beta_{3}=-0,198$; berarti apabila variabel love of money $\left(\mathrm{X}_{3}\right)$ meningkat, maka akan mengakibatkan penurunan pada persepsi mahasiswa mengenai profesi akuntan $(\mathrm{Y})$, dengan asumsi variabel bebas lainnya dianggap konstan.

Nilai koefisien determinasi menunjukkan seberapa jauh kemampuan variabel independen dalam menerangkan variasi variabel dependen. Nilai $R^{2}$ yang digunakan adalah adjust $R^{2}$ karena merupakan salah satu indikator untuk mengetahui pengaruh penambahan satu variabel independen ke dalam satu persamaan regresi. Tabel 4 menunjukkan bahwa nilai adjust $R^{2}$ (koefisien determinasi) adalah 0,517 ini artinya sebesar 51,7 persen variasi persepsi mahasiswa dipengaruhi oleh kecerdasan emosional, kecerdasan intelektual, dan love of money, sedangkan sisanya sebesar 48,3 persen dipengaruhi oleh faktorfaktor lain yang tidak dimasukkan ke dalam model penelitian.

Sebelum dilakukan pengujian hipotesis, satu hal yang perlu diperhatikan adalah kelayakan model penelitian yang dilakukan dengan uji $\mathrm{F}$ untuk mengetahui pengaruh variabel-variabel independen pada variabel dependen. Jika nilai sig $\mathrm{F}<$ $(\alpha=0,05)$ berarti variabel independen mempengaruhi variabel dependen dan variabel independen layak digunakan untuk memprediksi variabel dependen, sehingga pembuktian hipotesis dapat dilanjutkan. 
Berdasarkan hasil uji, nilai signifikansi $\mathrm{F}$ adalah sebesar 0,000 yang lebih kecil dari $0,05(\mathrm{~F}<\alpha)$ yang berarti variabel bebas yaitu kecerdasan emosional $\left(\mathrm{X}_{1}\right)$, kecerdasan intelektual $\left(\mathrm{X}_{2}\right)$, dan love of money $\left(\mathrm{X}_{3}\right)$ berpengaruh signifikan secara serempak atau bersama-sama terhadap variabel terikat yaitu persepsi mahasiswa (Y), sehingga penelitian ini dapat dikatakan memenuhi uji kelayakan model atau model penelitian dinyatakan layak digunakan sebagai model regresi.

Uji signifikansi (uji t) dilakukan untuk mengetahui pengaruh masing-masing variabel bebas terhadap variabel terikat. Level of significant $(\alpha)$ yang digunakan adalah 5 persen $(0,05)$. Apabila tingkat signifikansi $\mathrm{t} \leq \alpha=0,05$, maka $\mathrm{H}_{1}$ diterima dan $\mathrm{H}_{0}$ ditolak, namun bila tingkat signifikansi $\mathrm{t}>\alpha$, maka $\mathrm{H}_{1}$ ditolak dan $\mathrm{H}_{0}$ diterima.

Tabel 4 Menunjukkan tingkat signifikansi variabel kecerdasan emosional memiliki nilai koefisien beta positif sebesar 0,199 dengan nilai signifikansi sebesar 0,003. Nilai koefisien beta $>0$ dan nilai signifikansi $<0,05$ mengindikasikan bahwa kecerdasan emosional berpengaruh positif dan signifikan terhadap persepsi mahasiswa. Artinya, semakin tinggi tingkat kecerdasan emosional maka semakin tinggi persepsi mahasiswa mengenai etika profesi akuntan. Dengan demikian, H1 diterima.

Tingkat signifikansi variabel kecerdasan intelektual memiliki nilai koefisien beta positif sebesar 0,205 dengan nilai signifikansi sebesar 0,015. Nilai koefisien beta $>0$ dan nilai signifikansi $<0,05$ mengindikasikan bahwa kecerdasan intelektual berpengaruh positif dan signifikan terhadap persepsi mahasiswa. Artinya, semakin tinggi tingkat kecerdasan intelektual maka semakin tinggi 
Komang Intan Kurniasari dan I Gusti Ayu Nyoman Budiasih. Pengaruh...

persepsi mahasiswa mengenai etika profesi akuntan. Dengan demikian, H2 diterima.

Tingkat signifikansi variabel love of money memiliki nilai koefisien beta negatif sebesar -0,198 dengan nilai signifikansi sebesar 0,008. Nilai koefisien beta $<0$ dan nilai signifikansi $<0,05$ mengindikasikan bahwa love of money berpengaruh negatif dan signifikan terhadap persepsi mahasiswa. Artinya, semakin tinggi tingkat love of money maka semakin rendah persepsi mahasiswa mengenai etika profesi akuntan. Dengan demikian, H3 diterima.

Hasil analisis menunjukan koefisien regresi kecerdasan emosional memiliki tanda positif. Hal ini menjukan bahwa semakin tinggi sifat kecerdasan emosional mahasiwa akuntansi menyebabkan persepsi mahasiswa mengenai etika profesi akuntan. Hasil ini mendukung $\left(\mathrm{H}_{1}\right)$ yang menyatakan bahwa semakin tinggi tingkat kecerdasan emosional maka makin tinggi persepsi mahasiswa mengenai etika profesi akuntan. Dengan demikian mahasiswa yang memiliki sifat kecerdasan emosional yang tinggi dapat disimpulkan memiliki persepsi yang baik. Catarina (2010) Seseorang yang mampu mengatur emosional dengan baik maka akan timbul minat untuk mengembangkan potensi yang ada dalam dirinya, sehingga sumber daya manusia akan meningkat sesuai dengan kualitas yang diinginkan. Hasil penelitian ini sejalan dengan penelitian Dewi (2012) dan Agus Santika (2016).

Hasil analisis menunjukan koefisien regresi kecerdasan intelektual memiliki tanda positif. Hal ini menjukan bahwa semakin tinggi sifat kecerdasan intelektual mahasiwa akuntansi menyebabkan persepsi mahasiswa mengenai etika profesi 
akuntan. Hasil ini mendukung hipotesis $2\left(\mathrm{H}_{2}\right)$ yang menyatakan bahwa semakin tinggi tingkat kecerdasan intelektual maka makin tinggi persepsi mahasiswa mengenai etika profesi akuntan. Dengan demikian mahasiswa yang memiliki sifat kecerdasan intelektual yang tinggi dapat disimpulkan memiliki persepsi yang baik. Kecerdasan intelektual (IQ) Merupakan pengkualifikasian kecerdasan manusia yang didominasi oleh kemampuan daya pikir rasional dan logika. Lebih kurang $80 \%$, IQ diturunkan dari orangtua, sedangkan selebihnya dibangun pada usia sangat dini yaitu 0-2 tahun kehidupan manusia yang pertama. Hasil penelitian ini sejalan dengan penelitian Adinda (2015); Wechler dalam Pratiwi (2011); Yani (2011); William Stren dalam Purwanto (2003:52).

Hasil analisis menunjukan koefisien regresi love of money memiliki tanda negatif. Hal ini menjukan bahwa semakin tinggi sifat love of money mahasiwa akuntansi menyebabkan persepsi mahasiswa menurun ataupun sebaliknya yaitu semakin rendah sifat love of money mahasiswa akuntansi maka semakin tinggi persepsi mahasiswa akuntansi. Hasil ini mendukung Hipotesi $3\left(\mathrm{H}_{3}\right)$ yang menyatakan bahwa semakin tinggi tingkat love of money maka makin rendah persepsi mahasiswa mengenai etika profesi akuntan. Dengan demikian mahasiswa yang memiliki sifat love of money yang rendah dapat disimpulkan memiliki persepsi etis yang tinggi, hal ini sangat berguna untuk memberikan gambaran nantinya ketika sudah menyelesaikan perkuliahan dan bekerja sebagai seorang akuntan yang diharapkan memiliki integritas yang tinggi dalam menyelesaikan tugasnya karena bukan berpatokan kepada uang melainkan berpatokan pada etika 
dan norma yang berlaku serta pada undang-undang sesuai profesi seorang akuntan.

Hasil penelitian ini juga didukung oleh Chrismawati (2011) yang meneliti tentang analisis hubungan love of money terhadap persepsi etika mahasiswa akuntansi menunjukan bahwa love of money berpengaruh negatif terhadap persepsi mahasiswa akuntansi, hal ini disebabkan karena apabila seseorang memiliki kecintaan uang yang tinggi, maka ia akan berusaha untuk melakukan segala cara agar kebutuhannya terpenuhi namun tidak sesuai dengan etika. Selain itu penelitian ini sesuai dengan hasil dari penelitian Ari (2018) dan Aziz (2015).

\section{SIMPULAN}

Berdasarkan pembahasan hasil penelitian terhadap variabel-variabel bebas yang mempengaruhi persepsi mahasiswa mengenai etika profesi akuntan yang diukur dengan variabel kecerdasan emosional, kecerdasan intelektual, dan love of money dapat disimpulkan: 1) Kecerdasan emosional berpengaruh positif pada persepsi mahasiswa mengenai etika profesi akuntan. Hal ini menunjukkan bahwa semakin tinggi kecerdasan emosional yang dimiliki mahasiswa, maka semakin tinggi pula persepsi mahasiswa mengenai etika profesi akuntan; 2) Kecerdasan Intelektual berpengaruh positif pada persepsi mahasiswa mengenai etika profesi akuntan. Hal ini menunjukkan bahwa semakin tinggi kecerdasan intelektual yang dimiliki mahasiswa, maka semakin tinggi pula persepsi mahasiswa mengenai etika profesi akuntan; 3) Love of Money berpengaruh negatif pada persepsi mahasiswa mengenai etika profesi akuntan. Hal ini menunjukkan bahwa semakin 
tinggi sifat love of money yang dimiliki mahasiswa, maka semakin rendah persepsi mahasiswa mengenai etika profesi akuntan.

Berdasarkan simpulan tersebut, maka dapat disampaikan juga beberapa saran, yakni: 1) Mahasiswa sebagai calon akuntan dan auditor yang profesional, harus menghindari sifat dan prilaku yang tidak etis karena seorang akuntan da auditor merupakan tenaga profesional yang mengandalkan kepercayaan pada masyarakat; 2) bagi peneliti selanjutnya disarankan untuk memperluas ruang lingkup penelitian dengan mengambil sampel mahasiswa akuntansi dari perguruan tinggi negeri dan swasta lainnya; 3) disarankan untuk peneliti selanjutnya mengembangkan penelitian ini dengan meneliti faktor-faktor lain seperti profesionalisme dan idialisme yang memiliki pengaruh terhadap persepsi etis mahasiswa akuntansi yang tidak diteliti dalam penelitian ini.

\section{REFERENSI}

Adinda, K. (2015). Pengaruh Kecerdasan Emosional dan Kecerdasan Intelektual Terhadap Perilaku Etis Mahasiswa Akuntansi Dalam Praktik Pelaporan Laporan Keuangan. Skripsi Universitas Diponogoro Semarang.

Boyatzis, R., D. Goleman., dan K. Rhee. (2000). Clustering competence in emotional intelligence: Insights from the Emotional Competence Inventory (ECI). Handbook of Emotional Intelligence.

Catarina. (2010). Pengaruh Kepemimpinan Transformasional Dan Kecerdasan Emosional Terhadap Kinerja Karyawan. Jakarta: PT Gramedia Pustaka Utama.

Charismawati, C. D. (2011). Analisis hubungan antara love of money dengan persepsi etika mahasiswa akuntansi. Jurnal. Universitas Diponegoro.

Dewi, D. K. (2012). Pengaruh Kecerdasan Emosional, Norma Subjektif, Norma Perilaku, Kontrol Minat Pada Mahasiswa Berkarir Pendidikan Profesi Akuntansi. E-Jurnal Akuntansi Universitas Udayana, 20(2), 32-34. 
Ghozali, I. (2016). Aplikasi Analisis Multivariate Dengan Program IBM SPSS 23. Semarang: Badan Penerbit Universitas Diponegoro.

Goleman, D. (2000). Working With Emotional Intelligence. Jakarta: PT Gramedia Pustaka Utama.

Goleman. (2006). Emotional Intelligence: Kecerdasan Emosi, Mengapa EI Lebih Penting daripada IQ. Jakarta: PT Gramedia Pustaka Utama.

Higgs, M. (2002). Do leaders need emotional intelligence? A study of the relationship between emotional intelligence and leadership of change. International Journal of Organisational Behaviour.

Hoesada, J. (2002). Glosarium Keuangan. Yayasan Obor Indonesia.

Kurniawan, P. I. (2017). Pengaruh Love Of Money dan Machiavellian Terhadap Persepsi Etis Mahasiswa Akuntansi. E-Jurnal Akuntansi, 21(3), 15-18.

Lestari, I. G. A., I. M. S. Suardikha dan N. M. D. Ratnadi. (2016). Profesionalisme dan Locos Of Control Terhadap kinerja Auditor di Kantor Akuntan Publik Provinsi Bali. E-Jurnal Akuntansi, 13(1), 276-291.

Luna, A. R. dan T. L. P. Tang. (2004). The love of money, statisfaction, and the protestant work ethic: money profile among university professors in the USA and Spain. Journal of Bussines Ethic, 50, 329-54.

Mulyani, S. (2015). Analisis Pengaruh Jenis Kelamin dan Status Pekerjaan terhadap Persepsi Etis Mahasiswa Akuntansi dengan Love of Money sebagai Variabel Intervening. Solusi, 14(3).

Sugiyono. (2014) Metode Penelitian Pendidikan Pendekatan Kuantitatif, Kualitatif dan $R \& D$, Metode Penelitian Pendidikan Pendekatan Kuantitatif, Kualitatif Dan R\&D. Bandung: CV Alfabeta.

Sugiyono. (2016). Metodologi Penelitian Kuantitatif, Kualitatif, dan R\&D. Bandung: CV Alfabeta.

Tang, T. (1992). Money Profile: The Love of Money, Attidude, and Needs. Personel Review, 34(5), 603-624..

Tang, T. L. P., D. S. H. Tang., and R. Luna. (1992). Money profiles: The love of money, attitudes, and needs. Personnel Review. 